University of Michigan Law School

University of Michigan Law School Scholarship Repository

Articles

Faculty Scholarship

1923

\title{
International Aspects of Prohibition Enforcement
}

Edwin D. Dickinson

University of Michigan Law School

Available at: https://repository.law.umich.edu/articles/1050

Follow this and additional works at: https://repository.law.umich.edu/articles

Part of the Admiralty Commons, Food and Drug Law Commons, and the Supreme Court of the United States Commons

\section{Recommended Citation}

Dickinson, Edwin D. "International Aspects of Prohibition Enforcement." Mich. L. Rev. 21 (1923): 911-5.

This Response or Comment is brought to you for free and open access by the Faculty Scholarship at University of Michigan Law School Scholarship Repository. It has been accepted for inclusion in Articles by an authorized administrator of University of Michigan Law School Scholarship Repository. For more information, please contact mlaw.repository@umich.edu. 


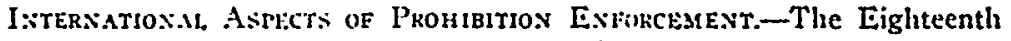
Amendment to the Federal Constitution prohibits "the manufacture, salc, or transportation of intoxicating liquors within, the importation thereof into, or the exportation thereof from the United States and all territory stbject to the juriscliction thereof for lseverage purposes." to Siat. 1050, 194t. In the diational P'rohibition Cast's, 253 L. S. 350, $3 \notin 6$, the amendment was said 
to be operative "throughout the entire territorial limits of the United States." As originally enacted, the National Prohibition Act did not in terms define its territorial field, but a supplemental provision afterwards enacted declares that the act "shall apply not only to the United States but to all territory subject to its jurisdiction." 42 Stat. 222. In other words, its field expressly coincides with that of the Amendment.

With the territorial field of national prohibition thus broadly defined, it has become necessary, in cases having rather important international complications, to determine what implied exceptions, if any, the courts may be justified in reading into amendment and statute in order to reconcile national prohibition with some of the customary incidents of friendly international intercourse. In the cases presented to date, the argument for implied exceptions has been conspicuously unsuccessful.

In Grogan v. Walker $\mathcal{E}$ Sons and Anchor Line v. Aldridge, decided together, 259 U. S. 80 , the Supreme Court held, in the one case, that notwithstanding prior statutory or treaty provisions to the contrary it is no longer permissible to ship intoxicating liquor in bond from Canada via Detroit to Mexico, and in the other case that liquor in transit from Scotland to Bermuda cannot be trans-shipped from one British ship to another in New York harbor. Mr. Justice Holmes said: "The routine arguments are pressed that this country does not undertake to regulate the habits of people elsewhere and that the references to beverage purposes and use as a beverage show that it was not attempting to do so; that it has no interest in meddling with transportation across its territory if leakage in transit is prevented, as it has been; that the repeal of statutes and a fortiori of treaties by implication is not to be favored; and that even if the letter of a law seems to have that effect a thing may be within the letter yet not within the law when it has been construed. We appreciate all this, but are of opinion that the letter is too strong in this case." And he continued: "The Eighteenth Amendment meant a great revolution in the policy of this country, and presumably and obviously meant to upset a good many things on as well as off the statute book. It did not confine itself in any meticulous way to the use of intoxicants in this country. It forbade export for beverage purposes elsewhere. * * It is obvious that those whose wishes and opinions were embodied in the amendment meant to stop the whole business." 259 U. S. $80,89$.

Following the decisions in Grogan v. Walker \& Sons and Anchor Line v. Aldridge, the Attorney General gave an opinion that it had been made unlawful to possess, transport, or sell intoxicating liquors for beverage purposes (I) on United States ships outside United States territorial waters and (2) on foreign ships inside United States territorial waters. In the Attorney Gencral's view, United States ships on the high seas were comprehended in the phrase, "the United States and all territory subject to the jurisdiction thereof," while the sweeping construction given the Amendment and the Act in the Grogan and Anchor Line cases necessarily precluded any implied exceptions in favor of foreign ships. Attorney, General's Opinion, Oct. 6, 1922. 
The Attomey General's construction was promptly contested by the shipping companies. It was sustained, however, by Judge Learned Hand in International Mercantile Marine $v$. Stuart, 285 Fed. 79 as regards United States ships outside United States territorial waters, and by the same judge in Cunard S. S. Co. v. Mellon, 284 Fed. 890 , as regards foreign ships inside United States territorial waters. It was urged in the latter case that intoxicating liquor as part of the ship's stores of a foreign merchant vessel was not within the rule, but the court denied the contention. It was a question, said Judge Learned Hand, of "implied limitations upon words which literally in any event cover the case." And after the decisions in the Grogan and Anchor Line cases, in which there were "much stronger reasons to imply an exception from the literal language of the act," he felt constrained to hold against the limitation for which the foreign shipping companies contended.

The district court's decision as regards United States ships outside United States territorial waters has recently been reversed by the Supreme Court, while its decision as regards foreign ships has been affirmed. Cunard Steamship Co. et al. v. Mellon, decided April 30, 1923. Until Congress has legislated more specifically, United States vessels may transport and sell intoxicating liquors on the high seas and in foreign waters. But foreign merchant vessels may not bring liquors for beverage purposes within the three-mile limit, not even as part of the ship's stores.

The cases presented to the Supreme Court called only for a construction of the terms in which the Amendment and the Act define the territorial field of prohibition. Those terms, it has already been indicated, are very simple and very explicit. In each instance the court attributed to them their natural and literal meaning.

As regards United States ships outside United States territorial waters, there appears to have been no substantial reason for construing the terms otherwise. The field of prohibition is expressly defined as the United States and territory subject to its jurisdiction. It is only in a metaphorical sense that a ship is ever said to be a floating bit of territory of the state whose

- flag it flies. See Scharrenberg v. Dollor S. S. Co., 245 U. S. 122; MIoore, DIGEST, I, \$ 174. The term "territory" in the Amendment and the Act means, said Mr. Justice Van Devanter, delivering the opinion of the court, "the regional areas-of land and adjacent waters-over which the United States claims and exercises dominion and control as a sovereign power." The term is used in a physical and not a metaphorical sense.

As regards foreign merchant ships within United States territorial waters, on the other hand, a very persuasive argument was made in favor of an implied exception. The argument was admirably epitomized in a dissenting opinion by Mr. Justice Sutherland. In the first place, it was said, "the general rule of international law is that a foreign ship is so far idlentified with the country to which it belongs that its internal affinirs, whose effect is confined to the ship, ordinarily are not subjected to interference at the hands of another state in whose ports it is temporarily present." See Wildcuhws's Case, 120 U. S. I, 12 (scmble); L'mited Stales i. Rogers, 150 
U. S. 249; 260 (scmble); Charteris, BRITISH YEAR BOOK OF INTERNATIONAL LAW, 1920-21, page 45; Wricht, 7 MiNN. L. Rev. 28, 32; Grecory, 2 Mich. L. REv. 333, 347; SCOTr, RESOLUTIONS OP THE INSTIMUTE OF INTERNATIONAL LAW, 143; HYDE, INTERNATIONAL, LAW, I, §§ 221 ff. In the second place, in the words of Chief Justice Marshall, in The Charming Betsy, $2 \mathrm{Cr} .64,118$, "an act of Congress ought never to be construed to violate the law of nations, if any other possible construction remains." See Wrighr, op. cit., 30-32. Mr. Justice Sutherland concluded as follows: "interference with the purely internal affairs of a foreign ship is of so delicate a nature, so full of possibilities of international misunderstandings, and so likely to invite retaliation that an affirmative conclusion in respect thereof should rest upon nothing less than the clearly expressed intention of Congress to that effect, and this I am unabie to find in the legislation here under review." See Brown v. Duchesne, $19 \mathrm{How}$. 183. Compare Caldwell v. Vanvlissingen, 9 Hare, 415. But see Act 15 and 16 Vict., ch. $83, \S 26$.

Cogent as Mr. Justice Sutherland's argument must be admitted to be, there would seem to be an even more persuasive answer. When the intention of Congress has been expressed as clearly and unequivocally as it is in the National Prohibition Act, and when Congress has made express exceptions where exceptions were intended (see Title III, § 20, excepting "liquor in transit through the Panama Canal or on the Panama Railroad," 4 I Stat. 322), it must be conceded that the courts ought to proceed slowly in creating implied exceptions by construction. Implied exceptions would undoubtedly be justified if required to insure the proper inmunities of foreign diplomats (see WrIGHT, op cit., 31) or the immunities of public ships. The Exchange, 7 Cr. I16. But the forcign merchant ship presents by no means so strong a case. It may be questioned, indeed, whether the regulation of intoxicating liquors in the stores of a foreign merchant ship is in any real sense analogous to the regulation of those matters of discipline and internal order with respect to which the territorial authority generally refrains from exercising jurisdiction. There would seem to be a much closer analogy between the inhibition of intoxicating liquor and some of the multifarious police regulations, port and harbor regulations, quarantine regulations, customs regulations, regulations in respect to loading, regulations in respect to life-saving appliances, or regulations in respect to the employment and compensation of crews to which merchant ships are commonly subject in foreign ports.

While the decision in Curard Steamship Co. v. Mellon seems sound enough, the majority opinion, unfortunately, is based upon an arbitrary and untenable premise. It is asserted that foreign merchant ships entering our territorial waters become absolutely subject to the territorial jurisdiction, and a dictum is quoted from The Exchange, supra, which, as an assertion of absolute sovereignty, would have filled with envy the foremost apologist for seventeenth century absolutism. Chief Justice Marshall made the statement quoted, it should be said, in no such spirit. In the context from which the passage is taken, it will be found to be no more than a step in the process of reasoning by which he elaborated a consensual theory of customary international law. This, however, the court ignores. And the court 
indicates that the premise of territorial absolutism has found support in numerous cases, none of which, as a matter of fact, are strictly in point. Thus, United States $v$. Diekelman, 92 U. S. 520 , was a case arising in a port under military control, in which clearance was withheld until alleged contraband had been unloaded. The reference to Wildenhus's Case, supra, is unfortunately to only a part of Chief Justice Waite's dictum. Nishimura Ekiu v. United States, I42 U. S. 651, involved the power to exclude aliens. Knott v. Botany Mills, I79 U. S. 69 , involved the application of Section I of the Harter Act, nullifying stipulations against liability for negligence, to a foreign vessel on a voyage from a foreign port to a port in the United States. Patterson v. Bark Eudora, 190 U. S. 169, and Strathearn S. S. Co. v. Dillon, 252 U. S. 348 , were cases in which the statute in question stipulated expressly that it should apply to foreign vessels. Compare Sandberg v. McDonald, 248 U. S. 185 , and Neilson v. Rhine Shipping Co., 248 U. S. 205. From such a premise, of course, the court experiences no difficulty in proceeding to the conclusion that the Amendment and Act were intended to apply to foreign ships in United States waters. It seems unfortunate, at this day, that the decision of a case having important international complications should have been thus supported.

Of the numerous international complications which have arisen out of prohibition enforcement, it may be added, the one which is in many respects the most interesting and most important still awaits a final determination. The writer refers to the question of seizures of foreign ships outside the three-mile limit. See The Grace and Ruby, 283 Fed. 475; United Siates v. 1,250 Cases of Liquor, 286 Fed. 260.

E. D. D. 